\title{
Stratejik İnsan Kaynakları Uygulamaları ile Otel İşletmelerinin Finansal Olmayan Örgüt Performansı Arasındaki İlişkinin Belirlenmesi
}

\section{Determination of Relationship Between Strategic Human Resources Applications and Non-Financial Organizations Performance of Hotel Enterprises}

Yrd. Doç. Dr. Ece KONAKLIOĞLU

Gazi Üniversitesi

Turizm Fakültesi

E-posta: ece@gazi.edu.tr Orcid Id:0000-0001-9326-1610
Ayşe ATAR

Gazi Üniversitesi

Sosyal Bilimler Enstitüsü

E-posta: ayseatar@gazi.edu.tr

Orcid Id:0000-0002-9060-668

Öz

Stratejik insan kaynakları yönetimi Türkiye gibi gelişmekte olan ekonomilerde kurumsal işletmelerin bile ilgisini yeni yeni çekmeye başlamış bir konu niteliğindedir. Stratejik insan kaynakları yönetimi çalışma kapsamında otel işletmeleri açısından ele alınarak işletmelerin finansal olmayan performansı kapsamında değerlendirilmektedir. Araştırma hipotezleri 209 orta kademe yöneticiden elde edilmiş veriler ile test edilmiştir. Çalışma verilerinin analizinde betimsel tekniklerden ve değişkenler arasındaki ilişkilerin ortaya konmasında ise ilişkisel testlerden yararlanılmıştır. Korelasyon değerinin belirlenmesi ile değişkenler arasındaki ilişkinin pozitif yönlü olduğu ortaya konulurken, çoklu regresyon analizi ile stratejik insan kaynakları uygulamalarının örgüt performansı üzerindeki etki katsayısı belirlenmiştir $(r=0,447)$.

Anahtar Kelimeler: Startejik insan kaynaklari yönetimi, örgüt performansı, otel, iş seçim süreci, eğitim, kurum içi işgücü piyasasi, işe alma süreci

\begin{abstract}
Strategic human resource management takes attention even corporate organizations hardly in the emerging economies like Turkey. In this study in terms of hotel enterprises, we evaluate the strategic human resource practices and the relationship between non-financial performances. We collect the data through 209 mid- level and senior managers of hotels which selected as sample of this study. In the analysis of the study data was analyzed with descriptive techniques and hypotheses of the research were tested by using multiple regression analysis. With this study, it is understood that organization performance is positively effected by strategic human resources practices $(r=0,447)$.
\end{abstract}

Key Words: Strategic human resource management, organizational performance, hotel, training process, internal labor market, recruitment process 


\section{Giriş}

Değişen çevre şartları ile birlikte rekabetin daha aktif hale gelmesi birçok örgüt için tehdit haline gelmiştir. Bu yoğun ve giderek artan rekabet ortamında örgütler, hem sürdürülebilir rekabet üstünlüğünü devam ettirebilmek hem de bulunduğu pazarda öncü konuma gelebilmek için maliyetleri düşürerek performanslarını arttırmak, ürün ve süreç inovasyonunu bünyesinde barındırmak, kaliteyi geliştirmek aynı zamanda pazara verimlilik ve hız kazandırmak durumundadırlar (Becker, Gerthart, 1996: 779). Amaçlanan bu hedeflere ulaşabilmek işletmenin bir örgüt kültürü mantığı ile bir bütün olarak ne kadar verimli ve birbirine bağlı çalıştığı ile ilgilidir. Hedeflenen amaçlara ulaşmasını sağlayan ve örgüt performansına etki eden önemli bir faktör de sahip olduğu insan kaynağıdır. İnsan kaynaklarının örgüt performansı üzerindeki etkisi stratejik insan kaynakları yönetimi açısından da değerlendirilmektedir. En basit haliyle stratejik insan kaynakları yönetimi bütün insan kaynakları yönetimi uygulamalarını birim ve işletme açısından bütüncül olarak kapsamasının yanı sıra bu uygulamaların örgüt uzun vadede performans üzerindeki etkilerini de ölçmeye çalışır (Lengnick-Hall, Lengnick-Hall, Andrade, Drake, 2009, 64)

Günümüzün karmaşık ve belirsizliklerle dolu dünyasında hemen hemen her alanda olduğu gibi insan kaynakları yönetimi alanında da stratejik yaklaşım bir zorunluluk haline gelmiştir (Yılmaz, 2009). Değişen çevre koşulları ortaya çıkan kapsamlı, karmaşık sorunlar ve yeni yönetim anlayışları, örgütsel verimlilik açısından en önemli rekabetçi üstünlük kaynağı olan insana, stratejik bir önem vermeyi kaçınılmaz kılmıştır (Way, Johnson, 2005:3). Çünkü zamanla insan faktörü, işletmeleri amaçlarına taşımakla görevli bir araç olmaktan çıkıp kaynak rolünü üstlenmiş ve işletmelerin en değer verdiği pozisyona geçmiştir (Barutçugil, 2004: 56; Altarawneh, 2016: 487).

Otel işletmeleri gibi işletmelerde ne derece büyük yatırımlar yapılırsa yapılsın, ne kadar yüksek sermaye ayrılırsa ayrılsın veya teknoloji kendisini aktif şekilde göstererek ne kadar ilerlerse ilerlesin, insan kaynaklarına gereken önem verilmediği sürece o işletmenin başarıya ulaşması güç olacaktır. Bu yüzden insan kaynakları yönetimine işletmenin en değerli varlığı gözü ile bakmak ve bu kaynağın var olan diğer üretim faktörlerine veya girdilere göre daha özel bir konuma sahip olması gerektiğini söylemek mümkündür. Çünkü bir işletmenin var olan girdileri (sermaye, doğal kaynak, teknoloji) tek başına hiçbir şey ifade etmezler. Bunların değerli kılan ve üretime dahil ederek aktif hale getiren insan kaynağıdır. Bu yüzdendir ki bir işletmede var olan stratejik insan kaynağı birimlerinin amacı bu girdilerden elde edilebilecek verimi en yüksek seviyeye çıkarmak ve bunun için gerekli olan faaliyetleri yerine getirmektir (Kaya ve Kesen, 2014: 98; Chen, Liav ve Lee, 2003: 315).

Stratejik insan kaynakları yönetimi uygulamalarının çalışanı temel alarak hareket etmesinden yola çıkılarak ulaşılabilecek sonuç stratejik insan kaynakları uygulamalarının temelde örgüt performansına etkisinin yadsınamaz olmasıdır. Stratejik insan kaynakları yönetimi uygulamalarının doğrudan örgüt çalışanlarını ilgilendirdiğine ve çalışan performansı üzerinde de etkisi olduğu düşünüldüğünde kavramın çalışanları ve örgütü ne derecede etkilediğinin, farklı sektörler açısından araştırılması gerekli olarak kendini göstermektedir (Erdem,1996: 1; Kaya ve Kesen, 2014: 99). Stratejik insan kaynakları uygulamalarının bir örgütün etkinliği ve verimliliğini belirleyen temel faktörlerden biri olarak karşımıza çıkması, stratejik insan kaynakları yönetimi uygulamalarının örgüt performansı üzerindeki rolünün anlaşımasını gerekli kılmaktadır. Insan kaynakları uygulamaları ve örgüt verimliliği veya performansı konuları ile ilgili yazında birçok çalışma olmasına rağmen (Way ve Jhonson 2005; 
Kaya ve Kesen, 2014; ülkemizdeki kurumsal işletmelerin bile yeni yeni ilgisini çektiği stratejik insan kaynakları yönetimi ile örgüt performansı arasındaki bağı sorgulayan çalışma sayısı oldukça sınırlıdır (Illiç ve Keçecioğlu, 2008). Bu nedenle çalışmanın amacı, stratejik insan kaynakları yönetimi uygulamalarının otel işletmelerinin örgüt performansına etkilerini araştırarak yazında var olan açığın kapatılmasına yardımcı olmaktır.

\section{Literatür}

\subsection{Stratejik İnsan Kaynakları Yönetimi ve Uygulamaları}

İnsan kaynakları bölümüne stratejik bakış açısının gelişmesi ile birlikte işletmeler her şeyi kendi olanakları ile kendi içerisinde yapmaya çalışan bir yapıdan, dışarıya ve değişime açık bir yapıya geçmeye başlamışlardır. Bunun yanı sıra insan kaynakları sadece üst yönetimin beklentilerine göre değerlendirilip hareket eden bir destek birim olmaktan çıkıp, iç ve dış çevre beklenti ve değerlendirmelerine göre kendini geliştiren bir yapıya ve işleyişe kavuşmuştur (Barutçugil, 2004: 57).

Stratejik insan kaynakları yönetimini Wright ve McMahan (1992) "bir işletmenin amaçlarına ulaşmasını sağlamak için planlanmış insan kaynakları düzenlemeleri ve iş modeli" olarak tanımlamışlardır (Barutçugil (2004: 56) ise, insan kaynakları yönetimine stratejik yaklaşımın, insan kaynakları bölümünü sınırlı bir alanda uzmanlık sunan dar bir bakış açısından kurtararak tüm birimler ve bireylerle iletişimi aktif konuma getiren, amaçlara ulaşma konusunda daha uzmanca yöntemler teknikler geliştirilmesini sağlayan güçlü bir merkeze dönüştüreceğini belirtmiştir. Aynı zamanda stratejik insan kaynakları yönetiminin, işletmenin var olan kültürünü geliştirmek, işletme performansını daha iyiye taşımak için işletmenin stratejik amaçları ve insan kaynakları yönetimi arasında da bağ kurduğu vurgulanmaktadır (Cingöz, 2011; Genç, 2009).

Stratejik insan kaynakları yönetimi anlayışı çevre faktörlerini ön planda tutarak işletme için iki boyutta toplanır bunlardan birincisi insan kaynakları fonksiyonlarının örgütsel hedeflere ulaşmada nasıl bir katkı sağlayacağı şeklinde tanımlanan insan kaynakları stratejileri, ikincisi ise insan kaynaklarının mevcut faaliyet alanlarını ifade eden insan kaynakları sistemidir (Way ve Jhonson, 2005:11). Faaliyet alanları ise kısaca aşağıdaki şekilde sıralanabilir;

- İş analizi; yapılacak olan işlerdeki görev sorumluluk ve çalışma koşullarının belirlenmesinin yanında bu işi yapacak olan iş görenin sahip olması gereken bilgi yetenek eğitim düzeyini en uygun biçimde belirlemek (Tortop,2006: 55; Okakın, 2008: 13; Ofluoğlu ve Bircan, 2007).

- İnsan kaynakları planlaması; bir işletme içerisinde çalışacak olan personelin hem sayı hem de nitelik açısından intiyaç olduğu kadar belirlenmesi ve bu ihtiyaca yönelik kaynakların önceden tespit edilmesi (Illic ve Keçecioğlu, 2009) ve bu intiyacın ne oranda karşılanabileceğinin belirlenmesine yönelik bir süreçtir (Erdem, 2004). Çevresel değişimlere cevap verip uyum sağlamasının yanında, mevcut personel ile ilgili her türlü faaliyeti de planlamak ve yönetmek gibi özelliklere sahiptir (Barutçugil, 2004: 244).

- İş gören seçimi ve işe alma; işletmeyi pozitif yönde etkileyecek ve verimliliğin artışını sağlayacak (Kaya ve Kesen, 2014; İlic ve Keçecioğlu, 2009; Karacan ve Erdoğan, 2011; Koçak ve Yüksel, 2011; Sabuncuoğlu, 2000: 72) kişilerin doğru pozisyona yerleştirilmesi(Akbaba ve Günlü, 2009,Çavdar, H ve Çavdar, M, 2010; Yüksel, 2003: 111).

- Eğitim; işletmenin performansı ile personelin eğitim seviyesinin doğru orantılı olması nedeniyle (Liu, Combs, Ketchen, ve Ireland, 2007; Karacan ve Erdoğan, 
2011) işletmede çalışan personelin işletmeye fayda sağlamas amacıyla yetişmesine olanak sağlamak (Illiç ve Keçecioğlu, 2009; Karacan ve Erdoğan, 2011).

- Performans değerlendirme; işletme çalışanları tarafından, verilen görev ve sorumlulukların yerine getirilip getirilmediğinin denetlenmesi (Akın ve Çolak, 2012) bir iş için görev ve sorumluluk verilen bireyin iş başında neyi ne kadar yapabildiğinin anlaşılması (Özgen, Öztürk ve Yalçın, 2005: 227-230).

- Ücretlendirme; verimliliği arttırmak ve daha iyi çalışmaya teşvik etmek için işletme içinde ödenecek ücret seviyesinin belirlenerek, belli bir ücret yapısı meydana getirmek ve bu iş görenlere emeğinin karşılığı olarak ödenecek ücretin ödenmesini sağlamak (Eren, Erdil ve Zehir, 2000; İliç ve Keçecioğlu, 2009).

\subsection{Finansal Olmayan Örgüt Performansı (Non-Financial/Operations-Based)}

Örgütsel performans muhasebenin temel ilgi alanında olmakla birlikte örgütsel amaçlara ne kadar ulaşıldığının sayısal bir kanıtı olarak görülmektedir. Ancak 1985 senesi ile ortaya çıkan yeni yönetim-üretim anlayışı, örgütsel performansın tek başına finansal açıdan değerlendirilmesinin yanıltıcı olabileceği düşüncesini ortaya çıkarmıştır. Özellikle bu konuda eleştirilerde bulunan Kaplan (1983), Drucker (1990) ve Conti (1993) finansal olmayan örgüt performansı dinamiklerinin örgütsel performansın değerlendirilmesinde göz önünde bulundurulması gerek önemli faktörler olduğunun altını çizmiştir. Finansal olmayan örgütsel performans göstergeleri genellikle konuyu ürün kalitesi ve pazarlama faaliyetleri açısından ele alarak performansı inceleme yoluna gitmektedir. Diğer bir ifade ile finansal olmayan örgütsel performans müşteri tatmini, personel verimliliği, ürünün kalite seviyesi ve müşteri ile sıcak temasta bulunan personelin işletme için merkezi rolü gibi konulara odaklanarak örgütsel performansın geliştirilmesini hedeflemektedir (Abdel-Maksoud, Dugdale ve Luther, 2005:262). Buradan hareketle örgütsel performans kavramı çalışma kapsamında örgütün kaynaklarını etkin ve verimli bir biçimde kullanarak amaçlarına ulaşabilme yeteneği (Başaran, 2000) olarak ele alınmış olup finansal olmayan performans dinamiklerini değerlendirmeye almaktadır.

Örgüt için performans, işletmenin nerede olduğunun, önceden başarılmak üzere belirlenen amaçların ne ölçüde başarıldığının ve en önemlisi, hâkim olduğu pazarda öncü konumuna gelebilmek ve söz sahibi olabilmek için yeteneklerin performans artışı sağlamak üzere nasıl etkili bir şekilde kullanacağının belirlenmesidir (Yılmaz ve Karahan, 2012: 158). Çalışan performansının artması genel anlamı ile işletme (örgüt) performansının artmasını sağlayacaktır. Bunun sebebi mevcut işletmenin sadece personelinin sergilediği performansı kadar belirlediği hedeflere ulaşabilecek olmasıdır (Way ve Jhonson, 2005:13). Bunun içinde yine stratejik insan kaynakları yönetiminin devreye girmesi ve var olan amaçlara ulaşmak için personelin sergilediği performansa olumlu düzeyde etki etmesi beklenmektedir. Çünkü stratejik insan kaynakları uygulamaları ile performansı pozitif yönde gelişen personel, bireysel performansının yanında bir bütün olarak örgütsel performansı arttırmakta. Bu artış sürekliliğini devam ettirmek isteyen, pazarda öncü konumuna gelmek isteyen işletmeler için rekabet gücünü yükselmektedir (Turunç, 2010: 254; Kaya ve Kesen, 2014: 107; Onay ve Kara, 2009: 598; Zhou, Hong, Liu, 2016: 263). Stratejik insan kaynakları yönetimi uygulamaları örgütün amaçlanan planlarını harekete geçirmek, sürdürülebilirliğini devam ettirebilmek ve örgütün var olan gücünü daha da arttırabilmek açısından önemlidir (Ralevic, Dragojlovic, Dobrodolac, Denic ve Nesic, 2015: 263).

Stratejik insan kaynakları yönetimi ve örgütsel performans ilişkisi üzerine yapılan çalışmalara bakıldığında, insan kaynakları uygulamalarından olan personeli seçme, işe 
alma, takım çalışması, eğitim süreci, performansları hakkında çalışanlara geri bildirim verme uygulamaları örgüt performansını arttıran insan kaynakları uygulamaları olarak gösterilmektedir (Kaya ve Kesen, 2014). Altarawneh'in (2016) banka yöneticileri üzerine yaptığı çalışmada ise, stratejik insan kaynakları yönetiminin örgütsel performansı pozitif yönde etkilediği, kar ve satış oranlarının artması, iş tatmininin ve işe bağlıığın yükselmesi yönünde etki gösterdiği çalışma sonucu olarak belirlenmiştir. Stratejik insan kaynakları yönetiminin örgüt performansı üzerindeki etkisini belirlemek üzere yapılan çalışmada stratejik insan kaynakları yönetiminin performansı olumlu yönde etkilemesinin yanı sıra aracılık etkisine de sahip olduğu firma inovasyonu arasında aracı etkisinin de olduğu gözlemlenmiştir (Zhou, Hong, Liu, 2013: 263). Bir başka aracılık rolü ise Mitcell, Obeiat ve Brat'ın (2013: 899) çalışmasında ortaya çıkmış ve bu çalışmada yüksek performans gösteren insan kaynakları yönetimi uygulamalarının stratejik insan kaynakları yönetimi ile örgütsel performans arasında pozitif aracılık rolü üstlendiği sonucuna ulaşılmıştır.

Insan kaynakları yönetimi ve örgütsel performans ile ilgili yapılan başka bir çalışmada insan kaynakları yönetiminin sosyal sorumluluk ile aralarında kuvvetli bir ilişki bulunmaktadır. Ayrıca insan kaynakları yönetimi uygulamalarının hizmet, başarılı büyüme ve örgüt performansına etkisinin olduğu belirlenmiş ve uzun dönemde bunun müşteri memnuniyeti yaratmasını da sağlayabileceği vurgulanmıştır (Borut, Amna, Simona, 2015: 228). İnsan kaynakları yönetiminin öneminin vurgulandığı Ralevic, Dragojlovic, Dobrodolac, Denic ve Nesic (2015: 263) yaptığı çalışma sonucu bize insan kaynakları yönetimi uygulamalarının hem bireysel hem de takım performansını arttırdığını uzun vadede ise örgütün sürdürülebilirliğini sağlayarak örgütsel performansı olumlu derecede etkilediğini göstermiştir. Turizm işletmeleri açısından ise bakıldığında stratejik insan kaynakları yönetimi ile örgütsel performansının turizm işletmeleri açısından değerlendirildiği çalışma sayısı hem uluslararası (Altarawneh, 2016) hem de ulusal yazında (Kaya ve Kesen, 2014) oldukça azdır. Buradan hareketle stratejik insan kaynakları yönetimi uygulamalarının (seçim süreci, eğitim süreci, işe alma süreci, kurum içi işgücü planlamasından oluşan stratejik insan kaynakları uygulamaları) otel işletmelerinin finansal olmayan örgüt performansı üzerindeki etkisinin değerlendirilmesinin alana katkı sağlayacağı düşünülmüş ve farklı sektörlerde yapılmış önceki çalışmaların varsayımları ışığında (Altarawneh, 2016; Borut, Amna, Simona, 2015; Ralevic, Dragojlovic, Dobrodolac, Denic ve Nesic, 2015; Kaya ve Kesen, 2014) araştırma sorunsalı ve alt hipotezleri oluşturulmuştur;

\section{Şekil 1: Araştırma Modeli}

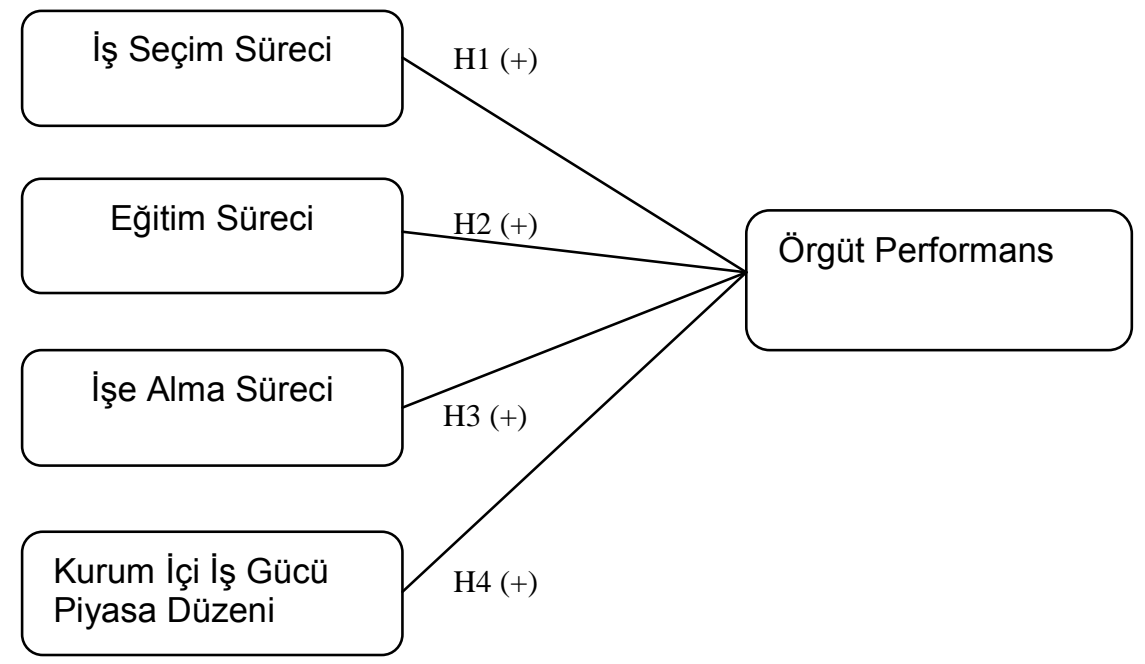


H1.Stratejik Insan kaynakları uygulamalarının örgüt performansı üzerinde istatistiksel olarak etkisi vardır.

H1.1 İs seçim sürecinin örgüt performansı üzerinde istatistiksel olarak etkisi vardır H1.2 Ĕgitim Sürecinin örgüt performansı üzerinde istatistiksel olarak etkisi vardır H1.3 Işe alma sürecinin örgüt performansı üzerinde istatistiksel olarak etkisi vardır H1.4 Kurum içi iş gücü piyasa düzeninin örgüt performansı üzerinde istatistiksel olarak etkisi vardır

\section{Araştırma Yöntemi}

Araştırma stratejik insan kaynakları yönetimi uygulamalarının örgüt performansı üzerindeki ilişki ve etkinin belirlenmesine odaklanarak Ankara'da faaliyet gösteren otel işletmelerini araştırma konusu yapmıştır. Otel işletmelerinin seçim nedeni ise gelişmekte olan ekonomilerde turizm sektörünün ekonomiye yaptığı katkıların stratejik önemi nedeniyle olmuştur. Ankara'nın seçim nedeni ise Başkent olması ve ikinci büyük nüfus oranına sahip olmasıdır. Diğer bir neden ise otel işletmelerinin son yıllarda bu destinasyondaki gelişimi ve artışıdır.

\subsection{Evren ve Örneklem}

Araştırma konaklama işletmelerinde çalışan orta ve üst düzey yöneticiler üzerinde yapılmıştır. Ankara ili içerisinde bulunan 4 ve 5 yıldızlı işletmeler hedeflenen evren olarak belirlenmiştir. Evrenin tamamına ulaşmanın zaman ve maliyet açısından güçlük çıkarmasından dolayı evren üzerinden örneklem alma yoluna gidilmiştir. Amaçlı örneklem olarak Ankara genelinde bulunan 16 adet 5 ve 42 adet 4 yıldızlı otelden farklı merkezlerde faaliyet gösteren ve çalışmaya katılmaya razı olan 32 konaklama işletmesinden orta ve üst kademede çalışan 270 yönetici belirlenmiştir. Araştırmaya katılmaya gönüllü olan 270 yönetici tarafından doldurulması istenen anketlerden 229 tanesi geri dönmüş bunlardan 20 tanesi eksik doldurma gibi nedenlerden dolayı analiz dışı bırakılarak 209 tanesi analize uygun bulunmuştur. Bu katılım sayısı bir kısıt olarak alınırken, araştırma sonuçları ancak uygulanılan örneklemi temsil yeteneğine sahiptir

\subsection{Verilerin Toplanması ve Ölçekler}

Araştırmada verilerin toplanmasında anket formundan yararlanılmıştır. Ölçeklerin pilot çalışması kapsamında güvenilirlik ve geçerlilik testleri sonucunda yeniden yapılandırımaya intiyaç duyulup duyulmadığı ayrı ayrı test edilmiştir. Soru formu 3 bölümden oluşmakta olup; birinci bölüm demografik ve katılımcıların iş hayatına ilişkin genel bilgileri içermektedir. İkinci bölüm stratejik insan kaynakları, üçüncü bölüm ise örgüt performansı ile ilgili önermelerden oluşmaktadır. İkinci ve üçüncü önermelere katılım derecesi 5'li Likert tipinde sorgulanmış olup, katılım derecesini ölçmektedir.

Araştırmada işletme içerindeki stratejik insan kaynakları yönetimi uygulamalarının ve örgüt performansının sorgulanması orta ve üst düzey yöneticiler vasıtasıyla gerçekleştirilmiş olup, Hester'in (2005) organizasyonel performans üzerinde stratejik insan kaynakları yönetiminin etkileri adlı çalışmasında kullanmış olduğu soru formunun uyarlanmış şeklidir. Stratejik İnsan Kaynakları Ölçeği 23 önermeden oluşan, 4 boyutlu ölçek formundadır. Örgüt performansı ölçeği ise beş önermeden oluşan tek boyutlu bir ölçektir.

Örgüt Performansı Ölçeği

Örneklemin, büyüklük açısından faktör analizi için veri yapısının uygunluğunu değerlendirmek amacıyla, KMO (Kaiser Meyer Olkin) değeri hesaplanmıştır. Bu 
değerin 0,844 olması nedeniyle veri yapısının faktör analizi yapılabilmesi için mükemmel derecede yeterli olduğu değerlendirilmesi yapılabilir (Çokluk, Şekercioğlu, Büyüköztürk, 2010: 2007).

Barlett testi sonuçları incelendiğinde ise elde edilen ki-kare $\left(X^{2}(10)=628,92 ; p<.01\right)$ değerinin 0,01 düzeyinde manidar olduğu görülmüş olup verilerin çok değişkenli normal dağlımdan geldiği kabul edilmiştir. Böylece faktör analizinin sonuçlarının değerlendirilmesine devam edilebileceğine karar verilmiştir.

Analizde faktör sayısının 1 olarak belirlenmesi nedeniyle, faktör yük değerleri arasındaki binişiklik problemi göz önünde bulundurulmamıştır. Tek faktörlü desenlerde açıklanan varyansın $\% 30$ ve daha fazlası yeterli görülürken, tanımlanan faktörün, toplam varyansa yaptığı katkının $(\% 70,992)$ yeterli olduğu görülmektedir.

\section{Tablo 1: Bileşen (Component) Matrisi Tablosu}

\begin{tabular}{|l|l|}
\hline & Bileşen \\
\cline { 2 - 2 } & 1 \\
\hline s24 &, 689 \\
\hline s25 &, 753 \\
\hline s26 &, 766 \\
\hline s27 &, 689 \\
\hline s28 &, 653 \\
\hline
\end{tabular}

Maddeler faktör yük değerleri açısından incelendiğinde ve yük değerleri kabul noktası 0,32 olarak kabul edildiğinde bu kabul düzeyini karşılamayan bir ifade ile karşılaşılmamıştır. Bu faktör analizinde madde çıkarmama kararı verilmiştir Stratejik Insan Kaynakları Uygulamaları Ölçeği:

Örneklemin, büyüklük açısından faktör analizi için veri yapısının uygunluğunu değerlendirmek amacıyla, KMO (Kaiser Meyer Olkin) değeri hesaplanmıştır. Bu değerin 0,894 olması nedeniyle veri yapısının faktör analizi yapılabilmesi için mükemmel derecede yeterli olduğu değerlendirilmesi bu ölçek için de yapılabilir.

Barlett testi sonuçları incelendiğinde ise elde edilen ki-kare $\left(X^{2}(253)=2761,456 ; p<.01\right)$ değerinin 0,01 düzeyinde manidar olduğu görülmüş olup verilerin çok değişkenli normal dağlımdan geldiği kabul edilmiştir. Böylece faktör analizinin sonuçlarının değerlendirilmesine devam edilebileceğine karar verilmiştir. Yapılan analiz sonucunda, maddelerin varyanslarının genellikle yüksek olduğu tespit edilmiştir. Açıklanan toplam varyans analizi sonucunda, faktör analizi için öz değerleri 1'in üzerinde olan 4 faktör önerilmektedir. 4 faktör önerilmesinin sebebi öz değerleri 1 'in üzerinde çıkan 4 bileşeni olmasıdır. 4 faktörün varyansa yaptığı katkının \%63,601 olduğu görülmektedir.

Stratejik insan kaynakları yönetimi uygulamaları ölçeğinin faktör desenini ortaya koymak amacıyla faktörleştirme yöntemi olarak temek bileşenler analizi; döndürme yöntemi olarak da dik döndürme yöntemlerinden döndürme işlemi (varimax-maximum değişkenlik ) seçilmiştir. Maddeler binişiklik ve faktör yük değerlerinin kabul düzeyini karşılayıp karşılamaması açısından değerlendirilmiştir. 5. ve 20. Maddelerin 1'den fazla faktörde kabul düzeyinden (0.32) yüksek yük değeri vermesi ve 2 faktörde de sahip olduğu yük değerleri asındaki farkın 0,1'den küçük olduğu görülmüştür. Bununla birlikte $14,15,18$ ve 19. Maddeler kendi grupları arasında yer almamıştır. Bu nedenle $5,14,15,18,19$ ve 20. Maddelerin ölçekten çıkarılmasına karar verilmiştir. 
Tablo 2: Madde Çıkartılmış Döndürülmüş Bileşenler Matrisi

\begin{tabular}{|c|c|c|c|c|}
\hline & \multicolumn{4}{|c|}{ Bileşenler } \\
\hline & 1 & 2 & 3 & 4 \\
\hline s2 & ,873 &, 043 & ,050 &, 096 \\
\hline s7 & 817 & ,217 & ,208 & ,042 \\
\hline s6 & ,786 &, 196 & ,212 &,- 035 \\
\hline s1 & ,761 & ,234 & ,076 & ,045 \\
\hline s3 &, 737 & ,101 & ,236 &, 060 \\
\hline s4 &, 566 & ,198 & ,366 & ,098 \\
\hline s11 &, 051 & 816 &, 106 &,- 043 \\
\hline$s 13$ &, 117 & 810 & ,011 &, 110 \\
\hline$s 10$ & ,261 & ,798 &, 114 & ,186 \\
\hline $\mathrm{s} 12$ &, 093 &, 791 & ,221 &, 046 \\
\hline s8 & ,286 & ,704 & ,067 & ,258 \\
\hline s9 & ,364 &, 560 &,- 040 & ,322 \\
\hline$s 23$ &, 084 &, 080 & ,883 &, 003 \\
\hline s22 & ,286 &, 094 & ,847 &, 094 \\
\hline$s 21$ & ,321 & , 140 & ,705 &,- 002 \\
\hline $\mathrm{s} 17$ &, 063 & ,128 &, 020 & ,875 \\
\hline $\mathrm{s} 16$ &, 045 & ,206 &, 066 &, 851 \\
\hline
\end{tabular}

Analiz dışı kalmış olan maddeler sonucu döndürülmüş bileşenler matrisi incelendiğinde, maddelerin teorik olarak tanımlanan yapılar altında yer aldığı belirlenmiştir. Bu noktada 4 faktörlü yapının varyansa yaptığı katkıyı belirlemek amacıyla açıklanan toplam varyans tablosu incelenmiştir. 5,14,15,18,19 ve 20. maddelerinin analiz dışı bırakılması ile 4 faktörün varyansı açıklama oranının \%69,320 olduğu görülmüştür. Bu çerçevede tanımlanan bir faktörün toplam varyansa yaptığı katkının yeterli olduğu söylenebilir.

Veri toplama amacıyla geliştirilmiş ölçekteki yargıların, soruların kendi aralarında tutarlı olup olmadıkları güvenilirlik analizi ile test edilmiştir. Alpha katsayısının değerlendirilmesinde uyulan değerlendirme ölçütüne göre sonuçlar Tablo 3'deki gibidir.

Tablo 3: Güvenilirlik Analizi Sonuçları

\begin{tabular}{|l|l|}
\hline Ölçek & Alpha Katsayısı $(\alpha=)$ \\
\hline Stratejik IKY & 0,919 \\
\hline Örgüt Performansı & 0,893 \\
\hline
\end{tabular}

Alpha katsayılarına bakıldığında, ölçeklerin güvenilirliğinin yüksek derecede olduğu belirlenmiştir (Özdamar, 1999).

\subsection{Verilerin Analizi}

Araştırmada elde edilen verilerin analizinde eri yapısına göre farklı istatistiksel yöntemler kullanılmıştır. Demografik ve kişisel bilgilerin analizinde tanımlayıcı istatistikler (yüzde, frekans, ortalama, medyan ve standart sapma) kullanılırken, değişkenler arasındaki ilişkinin varlığı ve yönünün belirlenmesinde ilişkisel testlerden korelasyon katsayısı, stratejik insan kaynakları uygulamalarının (Kurum içi iş gücü piyasası, İşe alma, Eğitim ve Seçim süreci) örgüt performansı üzerindeki etkisini belirlemek için ise çoklu doğrusal regresyon analizinden yararlanılmıştır. 
Analize geçilebilmesi için uç değerlerin olup olmadığı araştırılarak regresyon analizi için doğrusallık ve çok değişkenli normallik varsayımlarının karşılandığı görülmüştür. Grafiğin doğrusallık varsayımını karşıladığını gösteren standardize edilmiş sapma değerler ile standardize edilmiş tahmin değerleri grafiği şekil 2'de görülmektedir.

Şekil 2: Beklenen ve Gözlenen Birikimli Olasılık Grafiği

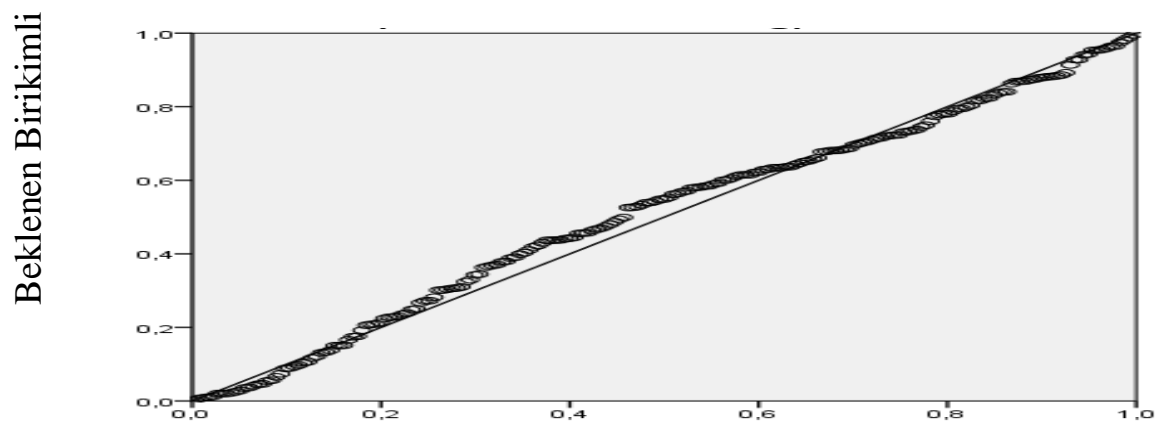

Gözlenen Birikimli Olasılık

Standardize edilmiş sapma deḡerlerle ilgili belirlenen gözlenen ve beklenen birikimli olasılık dağılımı grafiğinde dağılımın kare görüntüsünde olduğ ve normal dağılım açısından büyük bir sapma olmadığı görülmektedir (Şekil 3).

Şekil 3: Standardize Tahmini Değer ve Sapmalar

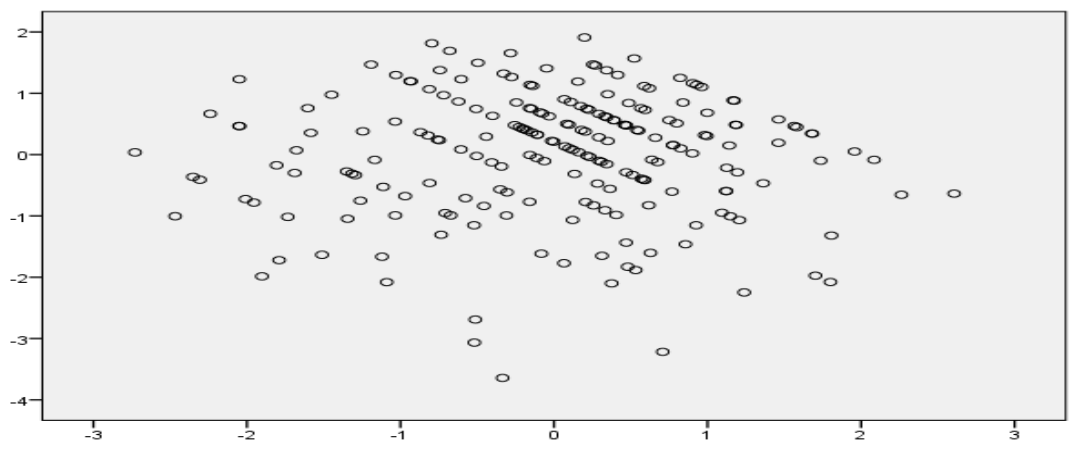

Standardize Sapmalar

\section{Bulgular}

Ankara'da faaliyette bulunan 4 ve 5 yıldızlı konaklama işletmelerinde görev yapan orta ve üst düzey yöneticilere uygulanan stratejik insan kaynaklarının ve örgütsel performansa etkisinin belirlenmesi amacıyla geliştirilmiş ve uygulanmış olan anket sonucu elde edilmiş verilerden yola çıkarak ulaşılmış olan bulgulara bu bölümde yer verilmiştir.

Araştırmaya katılan orta ve üst düzey yöneticilerin bireysel özelliklerine ilişkin verilerin analizinde tanımlayıcı istatistiklerden yararlanılmış olup yüzde ve sıklık değerleri tablo 4'de verilmektedir. 
Tablo 4: Orta ve Üst Düzey Yöneticilerin Bireysel Özelliklerine İlişkin Bulgular

\begin{tabular}{|c|c|c|c|}
\hline Demografik Bilgiler & & Sıklık & $\%$ \\
\hline Cinsiyet & Kız & 63 & 30,1 \\
& Erkek & 146 & 69,9 \\
\hline Yaş & $18-24$ & 4 & 1,9 \\
& $25-34$ & 87 & 41,6 \\
& $35-44$ & 94 & 45,0 \\
& $45-54$ & 23 & 11,0 \\
& 55 ve üzeri & 1 & 0,5 \\
\hline Gelir Durumu & $0-1000$ & 3 & 1,4 \\
& $1001-2000$ & 59 & 28,2 \\
& $2001-3000$ & 94 & 45,0 \\
& $3001-4000$ & 31 & 14,8 \\
& 4001 ve üzeri & 22 & 10,5 \\
\hline Eğitim Durumu & Lise & 35 & 19,1 \\
& Üniversite & 75 & 71,3 \\
& Diğer & 10 & 9,6 \\
\hline Çalışma Süresi & $<1$ Yıl & 30 & 14,4 \\
& $1-5$ Yıl & 86 & 41,1 \\
& $5-10$ Yıl & 64 & 30,6 \\
& $>10$ Yıl & 29 & 13,9 \\
& & & \\
\hline \multicolumn{3}{|c}{} \\
& & &
\end{tabular}

Tanımlayıcı istatistiklere bakıldığında konaklama işletmelerinde yer alan orta ve üst düzey yöneticilerin cinsiyete göre katılımının erkek yöneticiler üzerinde toplandığı $(\% 69,9)$ görülmektedir. Orta ve üst düzey yöneticilerinin çoğunluğunun yaş aralığı 2544 yaş arası olarak belirlenirken $(\% 86,6) 25$ yaşından önce $(\% 1,9)$ ve 55 yaşından sonra $(\% 0,5)$ ise nadir sayıda olduğu gözlemlenmiştir. Orta ve üst düzey yöneticilerin gelir durumuna bakıldığında, elde ettiği gelirleri 2001-3000 (\%45,0) arasında yoğunlaştığı, eğitim durumuna bakıldığında ise, eğitim seviyesi üniversite olan katılımcıların $(\% 71,3)$ sayısının daha yoğun olduğu gözlemlenmiştir. Orta ve üst düzey yöneticilerin mevcut işlerindeki yöneticilik süresinin çoğunlukla 1-5 yıl $(41,1)$ arasında olduğu ifade edilirken, 5-10 yıl $(\% 30,6)$ arası yöneticilik yapmış bireylerin de azınlıkta olmadığı görülmektedir.

Araştırmaya katılan orta ve üst düzey yöneticilerin stratejik insan kaynakları uygulamaları ile örgüt performansı arasındaki ilişkiyi belirlemek için korelasyon değerleri bulunmuştur. Stratejik insan kaynakları uygulamaları (iş seçim süreci, eğitim süreci, işe alma süreci, kurum içi iş gücü piyasa düzeni) ve örgüt performansı arasındaki korelasyon katsayıları tablo 5'de görülmektedir.

Tablo 5: Stratejik insan kaynakları uygulamaları (İş seçim süreci, eğitim süreci, işe alma süreci, kurum içi iş gücü piyasa düzeni) ve Örgüt Performansı Arasındaki Korelasyon Değerleri

\begin{tabular}{|l|l|l|l|l|l|}
\hline & 1 & 2 & 3 & 4 & 5 \\
\hline Örgüt Performansı & 1 & & & & \\
\hline Iş Seçim Süreci & $0,572^{* *}$ & 1 & & & \\
\hline Eğitim Süreci & $0,361^{* *}$ & $0,457^{* *}$ & 1 & & \\
\hline Işe Alma & $0,203^{* *}$ & $0,177^{* *}$ & $0,361^{* *}$ & 1 & \\
\hline Kurum İçi İş Gücü & $0,604^{* *}$ & $0,493^{* *}$ & $0,290^{* *}$ & 0,102 & 1 \\
\hline${ }^{*}$ p $<0,01$ anlamlılık düzeyinde (iki yönlü)
\end{tabular}


Tablo 5 incelendiğinde örgüt performansı ile stratejik insan kaynakları yönetimi uygulamalarının arasında doğrusal bir ilişki tespit edilmiştir. İş seçim süreci $(r=0.572$, $p<.01)$ ve kurum içi iş gücü piyasası $(r=0,604 ; p<.01)$ ile örgütsel performans arasında orta seviyede bir ilişki tespit edilirken, eğitim süreci $(r=0,361 ; p<.01)$ ve işe alma $(r=0,203 ; p<.01)$ zayıf bir ilişki ortaya konmuştur.

Örgüt performansı üzerinde stratejik insan kaynakları yönetimi uygulamalarının etki katsayısını belirlemek üzere çoklu doğrusal regresyon analizi testi yapılmıştır. Elde edilen sonuçlar tablo 6'da verilmektedir.

\section{Tablo 6: Stratejik Insan Kaynakları Uygulamalarıyla Örgütsel Performans Arasındaki İlişkiye Dair Çoklu Regresyon Analizi Sonuçları}

\begin{tabular}{|l|l|l|l|l|}
\hline Stratejik IKY & B & SS & Beta & T \\
\hline Sabit & 1,197 & 0,208 & & $5,766^{* *}$ \\
\hline Seçim & 0,291 & 0,057 & 0,323 & $5,137^{* *}$ \\
\hline Eğitim & 0,049 & 0,047 & 0,063 & 1,044 \\
\hline Işse alma & 0,050 & 0,034 & 0,080 & 1,478 \\
\hline Kurum içi işgücü & 0,350 & 0,049 & 0,419 & $7,165^{* *}$ \\
\hline Denek sayısı & 209 & & & \\
\hline $\mathrm{R}$ & 0,691 & & & \\
\hline$R^{2}$ & 0,477 & & & \\
\hline Düzeltilmiş $R^{2}$ & 0,467 & & & \\
\hline Standart Hata & 0,55 & & & \\
\hline F Değeri & $46,494^{* *}$ & & & \\
\hline Bağımlı değişken: örgütsel performans ${ }^{* *}=\mathrm{p}<.01$ &
\end{tabular}

Tablo 6'dan da görüldüğü üzere stratejik insan kaynakları uygulamalarından seçim, eğitim, işe alma ve urum içi iş gücü piyasası değerlerinin doğrusal kombinasyonunun örgütsel performansı anlamlı düzeyde etkilediği görülmektedir $\left(R^{2}=\right.$ .47) Regresyon denklemine giren değerler açısından seçim $(p<.01)$ ve kurum içi iş gücü piyasası $(p<.01)$ değerlerinin örgüt performansını etkilemede anlamlı olduğu görülmüş olup $H 1$ 1.1. ve $H 1.4$. alt hipotezleri kabul edilmiş, ana hipotez $(H 1)$ ise kısmen kabul edilmiştir. Söz konusu ilişkiye ait formül ise aşağıdaki gibi oluşturulabilir.

Örg. Perf $=1,197+0,291^{*}$ seçim $+0,350^{*}$ kur. içi işgücü

\section{Tartışma ve Sonuç}

Araştırmada turizm işletmelerinin örgütsel performansının, seçim süreci, eğitim süreci, işe alma süreci, kurum içi işgücü planlamasından oluşan stratejik insan kaynakları uygulamaları ile ilişkisi araştırılmıştır. Çalışma bulgularından yola çıkarak araştııılmış olan popülasyonu temsilen turizm işletmelerinin finansal olmayan örgüt performansı üzerinde stratejik insan kaynakları uygulamalarının olumlu etkisi olduğu düşünülmektedir $\left(R^{2}=.47\right)$.

Çalışmada örgütsel performansla stratejik insan kaynakları uygulamaları değişkenleri arasında doğrusal bir ilişki tespit edilmiştir. İş seçim süreci $(r=0.572$, $p<.01)$ ve kurum içi iş gücü piyasası $(r=0,604 ; p<.01)$ ile örgütsel performans arasında orta seviyede bir ilişki tespit edilirken, eğitim süreci $(r=0,361 ; p<.01)$ ve işe alma $(r=0,203 ; p<.01)$ arasında zayıf bir ilişki belirlenmiştir. Uzun zaman önce ortaya konan insan kaynakları ile örgüt performansı ilişkisi (Hiltrop, 1996, Becker, Gerhart, 1996) stratejik insan kaynakları açısından da araştırılmış olup önceki çalışmalara (Rogers, 
Wright, 1998) benzer olarak bu çalışama sonucunda da değişkenler arasında istatistiksel ilişki bulunmuştur.

İşletmelerin sürdürülebilir rekabet üstünlüğü sağlamak için örgütsel performansı artırma çabası, insan kaynakları departmanı başta olmak üzere yönetim kademesinin uzun vadeli planlamasını yakından ilgilendirmektedir. Diğer bir ifadeyle işletmelerin, özellikle personelin seçimi, işe alımı, eğitilmesi ve kurum içi iş gücünün değerlendirilmesi aşamasında, işletmenin amaç ve hedefleri çerçevesinde iç ve dış çevre dinamiklerine uyum sağlayabilme yeteneğine bakılması gerekmektedir. İK yönetiminin insan kaynakları sistemlerini geliştirmesi, sisteme uygun insan kaynağının belirlenmesi ve bu kaynağa yönelik stratejilerin geliştirilmesi Way ve Jhonson (2005)'ın öne sürdüğü gibi arzulanan örgüt çıktılarına ulaşmayı mümkün kılacaktır. Bu durum insan kaynakları departmanının turizm işletmelerinin örgütsel yapısı içindeki stratejik önemini farklı bir açıdan ortaya koyabilecek bir bulgu olarak ortaya çıkmıştır. Örgütsel başarı peşinde olan turizm işletmeleri için bu bulgu işletmelerin ileriye dönük uzun vadeli planlarının kapsamını farklılaştırabilir. İnsan kaynağının uzun vadede işletme içindeki stratejik önemini işetmelerin daha net görmesine olanak tanımaktadır.

Çalışmada kişilerin objektifliği varsayımı çerçevesinde sonuçlar değerlendirilmiş olup çalışmanın önemli bir sınırılığı olarak düşünülmektedir. Çalışmanın sınırlı bir örneklemi temsil yeteneğinin olması ise yine bir sınırlılık olarak ifade edilebilir. Demografik özelliklerin kontrol altına alınmadan ilişkinin değerlendirilmesi ise yine ayrı bir kısıttır. Diğer bir ifade ile farklı değişkenler de örgüt performansı üzerinde etkili olabilecektir dolayısıyla ilerideki çalışmaların farklı değişkenler çerçevesinde ve örgüt performansını bütüncül bir bakış açısıyla farklı popülasyonlardan elde edilecek verilerle ele almasının alana katkı sağlayacağına inanılmaktadır.

\section{Kaynakça}

Abdel-Maksoud, A., Dugdale, D. ve Luther, R. (2005), Non-Financial Performance Measurement in Manufacturing Companies, The British Accounting Review, 37:261-297.

Akbaba, A. ve Günlü, E. (2009), Otel işletmelerinde iş gören bulma, seçme ve eğitim sürecinin stratejik insan kaynakları bakış açısıyla değerlendirilmesi: Beş yıldızlı otellerde bir araştırma. Selçuk Üniversitesi Iktisadi ve Idari Birimler Fakültesi Sosyal ve Ekonomik Araştırmalar Dergisi, 9(18),ss. 1-25.

Akın, Ö. ve Çolak, H. E. (2012), İnsan kaynakları yönetimi uygulamalarıyla örgütsel performans arasındaki ilişki üzerine bir araştırma. Çankırı Karatekin Üniversitesi İktisadi ve Idari Bilimler Fakültesi Dergisi, 2(2), ss. 85-114.

Altarawneh, I. (2016), Strategic Human Resource Management and Its Impact on Performance: The Case From Saudi Arabia. International Journal of Business Management ad Economic Research, 7 (1), ss. 486-503.

Barutçugil, İ. (2004), Stratejik Insan Kaynakları Yönetimi (Birinci Baskı). Kariyer Yayıncılık İstanbul.

Başaran, İ. E. (2000), Örgütsel Davranış: Feryal Matbaası, Ankara.

Becker, B. ve Gerhart, B., (1996), The impact of human resource management on organizational performance: Progress and Prospects, Academy of Management Journal, 39(4), ss. 779-801

Borut, M., Amna, P ve Simona, Z. (2015), Social Responsibility, Human Resource Management, Organizational Performance. Systems Research and Behavioral Science: 32, ss. 221-229. 
Chen,L.H., Liaw,S.Y ve Lee, T.Z. (2003), Using an Hrm Pattern Aproach to Examine the Productivity of Manufacturing Firms: An Emprical Study. International Journal Of Manpower, (24) 3, ss. 299-318.

Cingöz, A. (2011), Stratejik İnsan Kaynakları Yönetimi Ve Stratejik İnsan Kaynakları Yönetiminin Örgütsel Performans Ve İç Girişimcilik( Girişimsel Performans) Üzerindeki Etkileri: Kayseri İmalat sanayinde Bir Araştırma, Doktora Tezi, Erciyes Üniversitesi Sosyal Bilimler Enstitüsü, Kayseri.

Conti, T., (1993), Building Quality: A Guide to Management. Chapman and Hall, London

Çavdar, H ve Çavdar, M. (2010), İşletmelerde işgören bulma ve seçme aşamaları. Journal of Naval Science and Engineering, 6(1), ss. 79-93.

Drucker, P.E., (1990), The emerging theory of manufacturing. Harvard Business Review, 94-102.

Erdem, F. (1996), İşletme Kültürü. Antalya, Akdeniz Üniversitesi Yayınları.

Erdem, B. (2004), Otel işletmelerinde insan kaynakları planlamasının yeri ve önemi. Iş, Güç Endütri İlişkileri ve Insan Kaynakları Dergisi, 6(1), ss. 36-54

Eren, E., Erdil, O ve Zehir, C. (2000), Türkiye de büyük işletmelerde uygulanan ücret ve maaş yönetim sistemi. Doğuş Üniversitesi Dergisi, 1(2),ss. 100-123.

Genç, K. Y. (2009). Stratejik İnsan Kaynakları Yönetimi-Örgütsel Performans İlişkisi Ve Türkiye'nin Büyük İşletmelerinde Yapılan Bir Uygulama, Doktora Tezi, Karadeniz Teknik Üniversitesi Sosyal Bilimler Enstitüsü, Trabzon.

Hester, L. J. (2005). The impact of strategic human resource management on organizational performance: A perspective of the resource-based view of the firm.,

http://dllibrary.spu.ac.th:8080/dspace/bitstream/123456789/2532/1/Stra\%20man $\% 20 \% 26 \% 20$ compet\%20advantage_Hester.pdf

Hiltrop, J.M. (1996), The Impact of Human Resource Management on Organisational Performance: Theory and Research, European Management Journal, 14 (6), ss. 628-637.

İliç, D. ve Keçecioğlu, T. (2008), Örgütsel Strateji İle İnsan Kaynakları Uygulamalarının Uyumlaştırıması Üzerine Bir Değerlendirme. Ege Akademik Bakış Dergisi, 11,ss. 1-23.

Kaplan, R.S., (1983), Measuring performance: a new challenge for managerial accounting research. The Accounting Review 18 (4), 686-705.

Karacan, E ve Erdoğan, N. Ö (2011), İşçi sağlığı ve iş güvenliğine insan kaynakları yönetimi fonksiyonları açısından çözümsel bir yaklaşım. Kocaeli Üniversitesi Sosyal Bilimler Enstitüsü Dergisi, 21(1),ss. 102-116.

Kaya, N ve Kesen, M. (2014), İnsan Kaynakları Yönetimi Uygulamaları ve Örgüt Kültürü Tiplerinin Çalışan Performansı Üzerindeki Etkilerini İncelemeye Yönelik Ampirik Bir Çalışma. Ekev Akademik Dergisi ,18 (58)ss. 97-122.

Keçecioğlu, T. (2009), İnsan kaynakları yönetiminden "stratejik" insan kaynakları yönetimine dönüşüm. Ege Akademik Bakış, 9(4), ss. 1171-1191

Koçak, O. ve Yüksel, S. (2011), İş gören seçiminde kullanılan yöntemler üzerine bir araştırma: Yalova Örneği. Kamu-Iş, Iş Hukuku ve Iktisat Dergisi, 12(1), ss. 73100.

Liu, Y., Combs, J.G., Ketchen, D.J. ve Ireland, R.D. (2007), The value of human resource management for organizational performance. Business Horizons, 50, ss. $503-511$.

Lengnick-Hall, M. L., Lengnick-Hall, C. A., Andrade, L. S. ve Brian Drake, (2009), Strategic human resource management: The evolution of the field, Human Resource Management Review, 19, ss. 64-85.

Mitcell, R., Obeiat, S ve Bray, M (2013), The Effect of Strategic Human Resource Management on Organizational Performance: The Mediating Role of High- 
Performance Human Resource Practices. Human Resource Management, 52(6), ss. 899-921.

Ofluoğlu, G. ve Bircan, H. (2007), Sağlık Hizmetlerinde İş Analizi Etkileri ve Zonguldak Atatürk Devlet Hastanesi Uygulaması. Kamu-İ̧s, İs Hukuku ve İktisat Dergisi, 9(2), ss. 75-118.

Okakın, N. (2008). Çalışma Yaşamında Insan Kaynakları Yönetimi (Birinci Baskı). İstanbul: Beta Basım.

Onay, M ve Kara, H. (2009), Lojistik Dış Kaynaklama Uygulamalarının Örgüt Performansı Üzerine Etkileri. Ege Akademik Bakış, 9 (2), ss. 593-622

Özgen, H., Öztürk, A. ve Yalçın, A. (2005). Insan Kaynakları Yönetimi (Birinci Baskı). Adana: Nobel Kitabevi.

Ralevic, V. P., Dragojlovic, A., Dobrodolac, M., Denic, M. N ve Nesic, Z. (2015), Increasing Organizational Performance By Huma Resource Management. Tehnicki Vjesnik, 22(2), ss. 263-269.

Rogers, E.W. ve Wright, P.M., (1998), Measuring Organizational Performance in Strategic Human Resource Management Problems, Prospect and Perpormance Informationa Markets , Human Resource Management Review, 8 (3), ss. 311331.

Sabuncuoğlu, Z. (2000), İnsan Kaynakları Yönetimi. Bursa: Ezgi Kitabevi.

Tortop, N., Aykaç, B., Yayman, H. ve Özer, M. A. (2006), Insan Kaynakları Yönetimi. Ankara: Nobel Basımevi.

Turunç, Ö. (2010), Organizasyonlarda Kontrol Algılamalarının Örgütsel Özdeşleşme ve İs performansına Etkisi, Cumhuriyet Üniversitesi Iktisadi ve Idari Bilimler Dergisi, (1)11, ss. 251-269.

Way, S.A. ve Johnson, D.E., (2005), Theorizing about the impact of strategic human resource management, Human Resource Management Review, 15, ss. 1-19.

Wright, P.M. ve McMahan, G. C. (1992), Theroretical perpectives for strategic human resource management. Journal Of The Management, June, ss. 295-320.

Yılmaz, H. (2009,). Insan kaynakları yönetimi uygulamalarının bilgi yönetimi stratejileri üzerine etkisi. 17. Ulusal Yönetim ve Organizasyon Kongresinde sunuldu, Eskişehir, 21-23 Mayıs.

Yılmaz, H ve Karahan, A. (2012), Dönüştürücü Liderliğin Bilgi Yönetim Süreçleri ve Örgüt Performansı Üzerindeki Etkileri: Tekstil Sektöründe Bir Araştırma. Sosyal Bilimler Dergisi, (5) 1, ss. 146-178.

Yüksel, Ö. (2003). Insan Kaynakları Yönetimi. Ankara: Gazi Kitabevi.

Zhou, Y., Hong, Y ve Liu, J. (2013), Internal Commitment or External Collaboration? The Impact of Human Resource Management Systems on Firm Innovation and Performance. Human Resource Management, 52(2), ss. 263-288. 